\title{
Pendampingan Pembelajaran Kanji Metode Pictogram secara Online bagi Siswa Pembelajar Bahasa Jepang di SMA Negeri 1 Ajibarang, Banyumas, Jawa Tengah
}

\author{
Stedi Wardoyo, Eman Suherman, Najih Imtihani \\ Fakultas Ilmu Budaya, Universitas Gadjah Mada \\ Korespondensi: stedi.wardoyo@ugm.ac.id
}

\begin{abstract}
Kanji is a Chinese character that was adopted and widely used in East Asian countries including Japan and several countries in Indochina region. Unlike the characters used by the nations of the world in general, the majority of which symbolize sound, Kanji are letters that symbolize meaning. Therefore, the number of Kanji characters is very large and the shapes and variations are very complicated. For Japanese learners, Kanji has an important meaning in mastering written language such as writing and reading. The kanji used by the Japanese have experienced adjustments, especially in terms of how to read which is adjusted to Japanese pronunciation. The large number, varied reading styles, and simple to complex letterforms make Kanji considered difficult by Japanese learners from nonKanji countries such as Indonesia. The advantages of Kanji letters are compact, the meaning can be immediately grasped, and beautifully written as if they are covered by the growing perception that Kanji is difficult due to the learning method that emphasizes the aspect of memorizing letter forms. To overcome this problem, it is necessary to develop a more interesting Kanji learning method by emphasizing understanding the meaning, especially for early-level learners so that they are interested and enthusiastic in learning Kanji so that it supports the Japanese learning process in general. One of the learning methods is the pictogram method which associates Kanji with its true meaning.
\end{abstract}

Keywords: Japanese language; Kanji; learning methods; pictogram

\begin{abstract}
Abstrak
Kanji merupakan huruf Mandarin yang diadopsi dan digunakan secara luas di negara-negara Asia Timur termasuk Jepang dan beberapa negara di wilayah Indocina. Berbeda dengan aksara yang digunakan bangsa-bangsa di dunia pada umumnya yang mayoritas melambangkan bunyi, Kanji merupakan huruf yang melambangkan makna/arti. Oleh karena itu, jumlah huruf Kanji sangat banyak dan bentuk serta variasinya sangat rumit. Bagi pembelajar bahasa Jepang, Kanji memiliki arti penting dalam penguasaan bahasa tulis seperti mengarang dan membaca. Kanji yang digunakan oleh bangsa Jepang mengalami penyesuaian terutama dalam hal cara baca yang disesuaikan dengan pelafalan bahasa Jepang. Jumlah yang banyak, cara baca yang bervariasi, dan bentuk huruf yang sederhana hingga rumit membuat Kanji dianggap sulit oleh pembelajar bahasa Jepang dari negara-negara non-Kanji seperti Indonesia. Keunggulan huruf Kanji yang ringkas (compact), langsung dapat ditangkap maknanya, dan indah dituliskan seakan tertutupi oleh persepsi yang berkembang bahwa Kanji itu sulit akibat metode pembelajaran yang lebih menekankan pada aspek menghafal bentuk huruf. Untuk mengatasi permasalahan tersebut perlu dikembangkan suatu metode pembelajaran Kanji yang lebih menarik dengan menekankan pada pemahaman makna, khususnya bagi pembelajar tingkat awal agar mereka tertarik dan
\end{abstract}


bersemangat dalam mempelajari Kanji sehingga mendukung proses pembelajaran bahasa Jepang secara umum. Metode pembelajaran tersebut salah satunya adalah metode pictogram yang mengasosiasikan Kanji dengan makna sebenarnya.

Kata Kunci: bahasa Jepang; Kanji; metode pembelajaran; pictogram

\section{Pendahuluan}

Pengajaran bahasa Jepang di Indonesia memiliki sejarah yang panjang sejak tahun 1960-an dan berdasarkan survei yang dilakukan The Japan Foundation di 142 negara pada tahun 2018, jumlah pembelajar bahasa Jepang di Indonesia menduduki peringkat kedua setelah Tiongkok dan peringkat pertama se-ASEAN, yakni sebanyak 703.306 orang (https://www.sukasuki.org/2020/01/). Jumlah ini didominasi oleh pelajar sekolah menengah atas yang mempelajari bahasa Jepang sebagai bahasa asing pilihan setelah bahasa Inggris. Meskipun peminat kelas bahasa Jepang cukup besar, pada kenyataannya, bahasa Jepang dianggap sebagai bahasa asing yang sulit bagi pembelajar Indonesia.

Selain tata bahasanya yang rumit, faktor lain yang memberatkan adalah adanya aksara Jepang, yakni huruf Kana dan Kanji, yang juga harus dipelajari oleh pembelajar di sekolah formal. Untuk huruf Kana yang terdiri atas Hiragana dan Katakana masingmasing berjumlah 46 huruf, pembelajar tidak membutuhkan waktu lama untuk menguasai karena jumlahnya terbatas, melambangkan bunyi, dan bentuknya sederhana. Namun, ketika memasuki materi huruf Kanji, banyak pembelajar yang kesulitan dan menganggap berat karena huruf Kanji merupakan simbol suatu makna tertentu dengan cara baca yang bervariasi dan jumlahnya banyak. Meskipun diperkirakan ada lebih dari 50 ribu huruf Kanji, saat ini huruf Kanji yang digunakan orang Jepang dalam kehidupan sehari-hari (jouyou kanji) berjumlah 2.136 huruf yang 1.006 hurufnya merupakan huruf Kanji yang diajarkan di sekolah (kyouiku kanji).

Meskipun bersifat pokok dan sangat penting - khususnya bagi pembelajar pemula yang ingin mengikuti Japanese Language Proficiency Test (JLPT) level terendah, yakni N5-pembelajaran Kanji di tingkat SMA di Indonesia masih bersifat tambahan dan pada umumnya dilakukan secara manual melalui pembelajaran tatap muka langsung di kelas. Metode yang dilakukan biasanya dengan menghafal bentuk Kanji, jumlah coretan, serta cara baca dan tulisnya. Tidak banyak inovasi yang dilakukan oleh guru dalam menyampaikan materi huruf Kanji ini, terlebih di tengah situasi pandemi Covid19 yang menghendaki pembelajaran secara online sehingga pembelajaran Kanji tidak bisa dilakukan secara optimal. Bagi siswa yang ingin menempuh ujian JLPT yang diselenggarakan secara serentak di seluruh dunia pada bulan Desember setiap tahunnya, kondisi ini dapat mengganggu proses pembelajaran dan pemenuhan target materi.

Program Studi Sastra Jepang, Fakultas Ilmu Budaya, Universitas Gadjah Mada sebagai salah satu bagian dari institusi yang menyelenggarakan kegiatan pendidikan/ pengajaran, penelitian, dan pengabdian kepada masyarakat yang berkaitan dengan bahasa, sastra, sejarah, dan kebudayaan Jepang merasa perlu untuk mengenalkan pembelajaran huruf Kanji dengan metode pictogram. Pendekatan ini menekankan pada pembelajaran secara holistik dengan cara mengasosiasikan huruf-huruf Kanji yang dipelajari dengan benda-benda konkret yang selaras dengan makna huruf Kanji tersebut. 
Wabah virus Corona atau Covid-19 yang oleh World Health Organization (WHO) pada tanggal 11 Maret 2020 secara resmi ditetapkan sebagai pandemi global dan menjangkiti lebih dari 123 negara di seluruh dunia, termasuk Indonesia (Harian Kompas, 12 Maret 2020) membawa dampak pada kehidupan, seperti sektor perekonomian, pariwisata, ketenagakerjaan, pendidikan, dan sebagainya. Dalam sektor pendidikan pemerintah Indonesia mulai 16 Maret 2020 sampai dengan saat ini menetapkan pembelajaran/perkuliahan mulai dari tingkat dasar sampai perguruan tinggi dilakukan secara daring (online). Universitas Gadjah Mada juga menetapkan seluruh kegiatan Tri Dharma Perguruan Tinggi (Pendidikan, Penelitian, dan Pengabdian kepada Masyarakat) dilakukan secara daring. Atas dasar situasi dan kondisi ini, tim kegiatan Pengabdian kepada Masyarakat mengadakan pendampingan pengajaran Kanji dengan metode pictogram ini secara daring kepada siswa-siswa pembelajar bahasa Jepang di SMA Negeri 1 Ajibarang, Banyumas, Jawa Tengah.

Pelaksanaan kegiatan didasari pada kebutuhan masyarakat, khususnya pembelajar bahasa Jepang yang akan mengikuti JLPT level N5 ke atas terkait dengan pembelajaran huruf Kanji secara efektif dan menarik. Dengan mengenal alternatif lain dalam pembelajaran Kanji, pembelajar diharapkan dapat belajar secara mandiri dan tidak tergantung pada pembelajaran di kelas yang waktunya relatif terbatas. Selain itu, kegiatan ini juga bertujuan untuk pengembangan metode pembelajaran Kanji agar mampu meningkatkan kemampuan siswa dalam memahami dan menguasai materi huruf Kanji.

Pemilihan sasaran kegiatan pada kelompok masyarakat, yakni guru bahasa Jepang dan siswa-siswa SMA Negeri 1 Ajibarang, lebih didasari pada alasan praktis dan analisis kebutuhan. SMA Negeri 1 Ajibarang setiap tahun secara aktif mendorong dan mengirimkan siswa-siswanya untuk menempuh Ujian Kemampuan Bahasa Jepang atau Japanese Language Proficiency Test (JLPT) yang diselenggarakan oleh The Japan Foundation secara serentak di seluruh dunia pada bulan Juli dan Desember sebagai salah satu tolok ukur keberhasilan pembelajaran. Program Studi Sastra Jepang FIB UGM sebagai mitra The Japan Foundation dalam bentuk kerja sama penyelenggaraan JLPT di wilayah Jawa Tengah dan D.I. Yogyakarta secara rutin menjalin komunikasi dengan pihak sekolah dalam proses pendaftaran siswa-siswa SMA Negeri 1 Ajibarang yang akan mengikuti ujian JLPT secara kolektif ke Yogyakarta. Berawal dari komunikasi tersebut, Tim PkM mencoba menghubungi pihak sekolah melalui guru bahasa Jepang, Bapak Widyantoro untuk menawarkan program PkM ini. Tawaran ini kemudian diteruskan kepada Kepala Sekolah dan memperoleh sambutan yang sangat positif dari pihak sekolah sehingga kerja sama ini dapat terlaksana.

\section{Sekilas tentang Kanji dan Sejarahnya}

Kanji 【漢字】 berasal dari kata “Kan【漢】” yang berarti 'negeri Kan atau Cina' pada masa dinasti Han (206 SM-220 M) dan 'ji【字】” yang berarti 'aksara atau huruf'. Huruf Kanji masuk ke Jepang pada awal abad ke-3 melalui interaksi perdagangan dan sosial budaya antara Jepang dan Tiongkok melalui Semenanjung Korea. Sebelum mengenal huruf Kanji, bangsa Jepang tidak mengenal aksara. Kanji merupakan huruf yang melambangkan arti/makna sehingga jumlahnya diperkirakan lebih dari 40.000 huruf. Namun, dalam kehidupan sehari-hari terdapat sekitar 5.000 huruf Kanji yang digunakan. Dalam perkembangannya, jumlah Kanji yang digunakan sehari-hari terus 
dibatasi dan pada tahun 2010, pemerintah menetapkan sejumlah 2.136 huruf Kanji yang digunakan secara resmi atau disebut Jouyou Kanji atau Kanji yang digunakan seharihari. Dari sejumlah 2.136 Kanji tersebut, di dalamnya terdapat Kyouiku Kanji (Kanji Pendidikan) sejumlah 1.006 yang diajarkan di sekolah dasar dan sisanya diajarkan di sekolah menengah pertama serta atas (https://jepang.org/daftarkanji/).

Masing-masing Kanji dituliskan dalam 1 coretan hingga lebih dari 30 coretan dan memiliki cara baca Mandarin (on-yomi) ataupun cara baca Jepang (kun-yomi). Cara baca on-yomi merupakan lafal bunyi bacaan orang Tiongkok yang ditransliterasikan ke dalam lafal Jepang, sedangkan kun-yomi merupakan cara baca atau istilah yang diucapkan orang Jepang untuk menyebut benda atau sesuatu untuk disimbolkan oleh Kanji tersebut. Sebagai contoh Kanji “日” yang secara harfiah berarti 'matahari' dibaca $n i$ atau nichi dalam on-yomi, sedangkan dalam bahasa Jepang 'matahari' disebut hi. Dalam satu huruf Kanji terkadang memiliki lebih dari satu on-yomi maupun kun-yomi bergantung dari konteksnya meskipun tidak semua Kanji selalu memiliki on-yomi atau kun-yomi. Pada masa-masa awal, huruf Kanji digunakan dan berkembang di kalangan istana serta pendeta Buddha.

Akibat jumlah Kanji yang banyak, cara baca yang berbeda untuk Kanji yang sama, cara penulisan yang rumit, serta pertimbangan praktis untuk mempermudah pengenalan budaya baca tulis di kalangan masyarakat luas pada abad ke-7, dibuatlah huruf Kana yang merupakan hasil modifikasi dan penyederhanaan huruf Kanji. Upaya ini juga dimaksudkan untuk mengatasi permasalahan gramatikal yang berbeda antara bahasa Jepang dan Mandarin yang bila dituliskan semua dengan huruf Kanji akan menimbulkan kerancuan. Berbeda dengan Kanji yang melambangkan arti/makna, huruf Kana melambangkan pada bunyi yang dibedakan atas Hiragana untuk menuliskan kata-kata asli Jepang yang tidak dituliskan dengan Kanji dan Katakana, yang digunakan untuk menuliskan kata serapan dari bahasa asing. Baik Hiragana maupun Katakana, semuanya berjumlah masing-masing 46 huruf. Hingga kini, bangsa Jepang menggunakan huruf Kanji, Kana, dan huruf Romawi secara terbatas dalam kehidupan sehari-hari.

Dalam JLPT, Kanji menjadi materi penting dalam ujian dan menjadi salah satu bagian yang diujikan bersama materi kosakata. Untuk level terendah dalam JLPT, yakni level N5, peserta ujian dituntut memiliki penguasaan Kanji Dasar sejumlah sekitar 100 huruf. Soal ujian Kanji yang terintegrasi dengan materi Tata Bahasa dan Kosakata memiliki porsi sekitar 25\%. Selain menjadi materi yang diujikan, Kanji juga digunakan dalam penulisan seluruh soal bersama huruf Hiragana dan Katakana dengan menyesuaikan level ujian. Dalam kegiatan Pengabdian kepada Masyarakat ini, jumlah Kanji yang diajarkan melalui metode pictogram adalah sekitar 68 huruf dari sekitar 100 Kanji yang masuk dalam daftar Kanji untuk JLPT N5. Kanji-kanji tersebut dipilih berdasarkan dapat tidaknya dibuat pictogram, mengingat tidak seluruh Kanji dapat dijadikan pictogram, selain pertimbangan-pertimbangan lain seperti frekuensi kemunculannya dalam soal ujian maupun pertimbangan praktis menyangkut waktu, biaya, dan tenaga.

\section{Huruf Kanji sebagai Pictogram}

Kerumitan-kerumitan huruf Kanji sebagaimana diuraikan di atas menyebabkan Kanji 
dipandang sulit untuk dipelajari oleh orang asing, khususnya pembelajar dari negaranegara non-Kanji seperti Indonesia. Selain itu, bagi pembelajar tingkat awal, Kanji dapat menjadi hambatan dalam pembelajaran apabila menimbulkan kesan bahwa belajar huruf Kanji sulit dan tidak menarik akibat penggunaan metode pembelajaran yang konvensional serta tidak didukung media pembelajaran yang menarik dan tepat. Untuk mempermudah pembelajaran huruf Kanji, diperlukan kiat-kiat tertentu agar Kanji mudah dipahami, dihafal, dan diterapkan oleh pembelajar bahasa maupun budaya Jepang. Salah satu metode yang dapat ditempuh adalah metode pictogram, yakni menangkap makna dari simbol-simbol yang terdapat dalam huruf Kanji tersebut dan mengasosiasikannya dengan bentuk fisik benda yang disimbolkannya secara nyata. Hal ini dimungkinkan mengingat beberapa Kanji tercipta dari unsur-unsur yang secara langsung dapat diasosiasikan dengan benda nyata yang disimbolkannya. Beberapa contoh pictogram huruf Kanji adalah sebagai berikut.
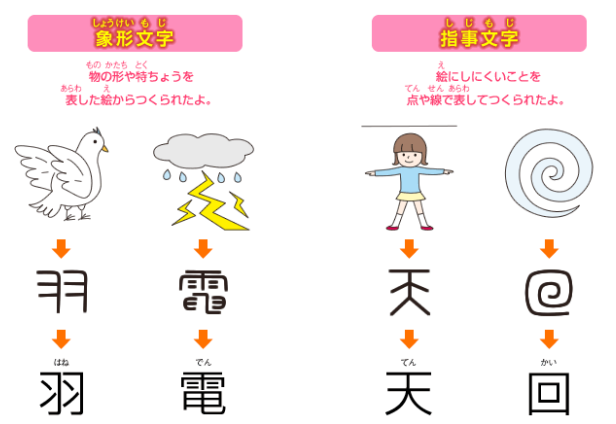
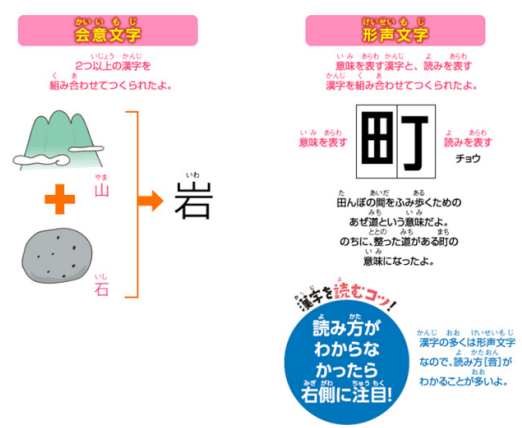

Gambar 1. Contoh pictogram huruf Kanji.

(Sumber: https://www.chuden.co.jp/kids/denkipaper/2013/692/issue02.html)

Selain mengasosiasikan secara langsung dalam bentuk nyata benda yang diartikannya, Kanji juga merupakan gabungan beberapa huruf sederhana sehingga membentuk suatu gambar peristiwa atau pemandangan tertentu. Sebagai contoh, Kanji 'hutan' atau dalam bahasa Jepang disebut mori【森】terdiri atas tiga Kanji pohon atau $k i$ 【】 sehingga dapat diasosiasikan sebagai kumpulan pohon dalam jumlah banyak atau hutan rimba. Kanji pohon atau $k i$ 【木】menjadi unsur pokok pembentuk huruf Kanji atau disebut bushu, yang digunakan untuk huruf-huruf Kanji yang memiliki makna berkaitan dengan pepohonan atau perkayuan. Sebagian besar Kanji dapat dikenali maknanya melalui bushu dari Kanji tersebut. Melalui pengenalan bushu, pembelajar Kanji tingkat awal hingga mahir dapat lebih mudah menangkap makna di balik sebuah Kanji selain dari asosiasi secara visual langsung pada bendanya. Dengan metode pictogram ini, huruf Kanji sebagai lambang visual yang relatif sulit untuk ditangkap dan disimpan oleh memori manusia akan lebih mudah ditangkap oleh memori ketika diubah ke dalam bentuk gambar hidup ataupun gambar mati. Atas dasar asumsi-asumsi tersebut, tema pengabdian kepada masyarakat ini adalah pembelajaran Kanji tingkat dasar (JLPT N5) melalui metode pictogram secara daring kepada siswa pembelajar bahasa Jepang di SMA Negeri 1 Ajibarang, Banyumas. 


\section{Pendekatan Pelaksanaan Program}

Pembelajaran Kanji pada ranah akademis umumnya dilakukan secara konvensional dengan menekankan pada hafalan bentuk Kanji, cara tulis, dan cara bacanya. Metode ini relatif sulit diingat oleh pembelajar karena bersifat abstrak dan jumlah Kanji yang sangat banyak. Untuk memudahkan pemahaman dan penyimpanan dalam memori, metode pictogram yang menekankan pada pengalaman indrawi, terutama visual, dapat dijadikan sebagai alternatif dalam pengajaran Kanji. Dengan pelibatan panca indra secara menyeluruh meliputi penglihatan, pendengaran, dan sentuhan dalam bentuk praktik penulisan diharapkan informasi yang diterima oleh pembelajar akan mudah diingat dan dipraktikkan.

Pembelajaran Kanji dalam kurikulum pelajaran bahasa Jepang untuk siswa SMA dan SMK di Indonesia tidak dilakukan secara khusus pada jam pelajaran tersendiri, tetapi terintegrasi pada materi lain, terutama tata bahasa dan percakapan. Selain itu, pembelajaran Kanji lebih bersifat pelengkap sehingga tidak ada target-target tertentu yang ditetapkan dalam kurikulum bahasa Jepang sehingga guru lebih banyak menentukan sendiri penjadwalan maupun target pembelajarannya. Berdasarkan informasi dari guru bahasa Jepang SMA Negeri 1 Ajibarang, Bapak Widyantoro, diperoleh informasi bahwa target pembelajaran Kanji dari kelas X-XII di sekolahnya adalah setara Japanese Language Proficiency Test (JLPT) level terendah, yaitu N5. Setiap tahun SMAN 1 Ajibarang mendorong dan memfasilitasi siswanya untuk mengikuti JLPT yang diselenggarakan secara serentak di seluruh dunia di Yogyakarta atau Semarang sebagai salah satu tolok ukur pembelajaran. Adanya keterbatasan waktu pembelajaran Kanji di kelas, sedangkan target pembelajaran Kanji untuk JLPT minimal N5, membuat guru selalu mengimbau siswa untuk belajar secara mandiri. Adanya pandemi Covid-19 yang memaksa pembelajaran secara daring membuat proses pembelajaran dan pendampingan untuk siswa tidak dapat dilaksanakan secara optimal. Atas dasar hal tersebut, tim PkM memandang perlu untuk membantu mengatasi permasalahan-permasalahan tersebut dengan menawarkan sebuah alternatif pembelajaran Kanji dengan metode pictogram secara daring.

Kegiatan Pengabdian kepada Masyarakat ini lebih menekankan pada pengenalan dan pendampingan kepada guru bahasa Jepang di SMA maupun SMK secara umum dan secara khusus kepada guru dan siswa SMA Negeri 1 Ajibarang. Dengan adanya metode pendampingan ini, diharapkan guru bahasa Jepang dapat memberikan alternatif pembelajaran huruf Kanji kepada siswa-siswanya dan diharapkan dapat mengembangkan metode pictogram dengan menyesuaikan situasi dan kebutuhan di lapangan. Selain pendampingan kepada guru kelas, kegiatan ini juga sekaligus menjadi pilot proyek atau mini research terkait dengan pengajaran Kanji melalui pendekatan classroom action research (penelitian tindakan kelas) mengingat pengajaran Kanji ini memiliki potensi untuk dikembangkan lebih lanjut dan diterapkan dalam perkuliahan, baik bagi mahasiswa Program Studi Sastra Jepang UGM maupun mahasiswa/masyarakat pembelajar bahasa Jepang di Indonesia.

Untuk mengarah pada sasaran dan tujuan tersebut di atas, metode yang dilaksanakan dalam kegiatan ini meliputi perencanaan (plan), pelaksanaan tindakan (action), pengamatan (observation), dan refleksi (reflection). Selain itu, kegiatan ini juga bersifat partisipatoris kolaboratif sehingga dalam setiap tahapan kegiatan dilakukan dengan 
melibatkan guru kelas, yakni Bapak Widyantoro. Secara garis besar, tahapan-tahapan kegiatan yang dilaksanakan adalah sebagai berikut.

\section{A. Perencanaan}

- Penyusunan rencana pelaksanaan kegiatan Pengabdian kepada Masyarakat secara kolaboratif antara Tim PkM dan guru pengampu kelas bahasa Jepang.

- Penyusunan instrumen tes penjajagan dan tes akhir berdasarkan materi ujian Kanji JLPT N5.

- Penyiapan media pembelajaran menggunakan metode pictogram dalam bentuk video dan buku latihan.

\section{B. Pelaksanaan dan Pengamatan}

- Sosialisasi dan diskusi terkait dengan materi dan metode pembelajaran bersama guru kelas dan pihak sekolah.

- Melaksanakan tes penjajagan awal secara daring untuk mengetahui kemampuan awal siswa dalam penguasaan Kanji JLPT N5.

- Membagikan video dan buku latihan Kanji JLPT N5 untuk memberikan kesempatan siswa mengenal dan mempraktikkan cara belajar Kanji menggunakan pictogram.

- Melaksanakan webinar tentang prospek belajar bahasa asing, khususnya bahasa Jepang, arti penting JLPT, dan materi utama terkait pembelajaran Kanji, khususnya metode belajar Kanji menggunakan pictogram dengan nara sumber Tim PkM dan guru kelas.

- Melaksanakan ujian akhir (post test) untuk mengetahui efektivitas dan perbedaan hasil pembelajaran Kanji sebelum dan sesudah perlakuan.

\section{Refleksi}

Setelah pelaksanaan kegiatan, dilakukan evaluasi terhadap seluruh rangkaian kegiatan untuk mengetahui keberhasilan atau kegagalan program kegiatan ini. Proses ini selain melibatkan guru kelas juga meminta saran dan pendapat siswa atas program pembelajaran Kanji menggunakan metode ini. Saran dan pendapat yang masuk menjadi catatan bagi perbaikan dan penyempurnaan materi dan metode pembelajaran selanjutnya.

\section{Pelaksanaan Program}

\section{Persiapan}

Sebuah program dan kegiatan yang baik haruslah direncanakan dengan baik pula. Untuk itu, Tim PkM berusaha semaksimal mungkin melakukan persiapan untuk pelaksanaan program PkM ini. Tim pengabdi melakukan beberapa kali pertemuan untuk menentukan jadwal kegiatan, pembuatan modul kegiatan, pembuatan tes awal dan tes akhir, koordinasi kunjungan lokasi, pelaksanaan webinar dan menentukan penanggung jawab masing-masing kegiatan tersebut. Koordinasi dilaksanakan secara daring maupun luring dengan memperhatikan protokol kesehatan Covid-19.

\section{Pembuatan modul}

Pembuatan modul pelatihan diperlukan agar peserta kegiatan lebih mudah memahami materi yang akan disampaikan dalam webinar. Selain itu, modul pelatihan juga dapat 
digunakan untuk panduan pembelajaran mandiri bagi siswa di rumah dalam belajar huruf Kanji dan persiapan mengikuti ujian JLPT. Kegiatan ini dimulai dari menentukan jumlah Kanji yang akan diajarkan, mencari bahan rujukan, membuat kompilasi dari setiap bahan rujukan, menentukan susunan dan materi modul, penyusunan modul, mencetak dan mendistribusikan modul kepada siswa melalui sekolah.

\section{Pembuatan video}

Setelah modul selesai, langkah berikutnya adalah membuat video pembelajaran Kanji metode pictogram. Untuk memudahkan pembelajaran, sejumlah Kanji tersebut dikelompokkan dalam beberapa tema yaitu Kanji tentang alam, manusia dan keluarga, angka dan waktu, posisi dan tempat, kata sifat, kata kerja, dan tema lainnya. Pembuatan video dimulai dengan membuat gambar animasi dari masing-masing Kanji, kemudian menyusun dan mengeditnya menjadi video.

\section{Kunjungan lokasi}

Setelah modul dan video pembelajaran selesai dibuat, Tim PkM mengadakan kunjungan lokasi yang menjadi sasaran program PkM ini, yaitu SMAN 1 Ajibarang, Kabupaten Banyumas. Kunjungan lokasi dilaksanakan sebagai sarana sosialisasi dan konsolidasi dengan guru pengampu bahasa Jepang dan pihak sekolah mengingat keterbatasanketerbatasan dalam hal komunikasi secara daring. Atas izin Kepala Sekolah SMA Negeri 1 Ajibarang mengingat situasi pandemi Covid-19 yang menuntut adanya pembatasan interaksi langsung, kunjungan lokasi terlaksana pada Jumat, 10 September 2020, mulai pukul 10.00-16.00 dengan tetap memperhatikan Protokol Kesehatan. Pada pagi hari, Tim PkM ditemui oleh Bapak Widyantoro, selaku guru pengampu bahasa Jepang yang menjelaskan kondisi pembelajaran bahasa Jepang di SMA tersebut. Beliau menjelaskan bahwa jumlah total pembelajar bahasa Jepang ada lebih dari 130 siswa mulai dari kelas $10-11$. Sebagian besar pembelajar berasal dari jurusan sosial dan bahasa. Selain berdikusi tentang permasalahan pengajaran bahasa Jepang di SMAN 1 Ajibarang, Tim juga melakukan koordinasi pelaksanaan webinar yang akan dilaksanakan seminggu setelah kunjungan lokasi. Tim juga menjelaskan cara pemakaian modul dan video Kanji pictogram.

Pada pukul 13.00, Tim PkM bertemu dengan pimpinan SMAN 1 Ajibarang yang terdiri atas Kepala Sekolah, Wakasek Humas, Wakasek Kurikulum, Wakasek Sarana dan Prasarana, Kepala Bagian Administrasi, dan Staf Bagian Teknologi Informasi, dan guru pengampu Bahasa Jepang. Bertempat di ruang rapat utama SMAN 1 Ajibarang, Tim PkM dan Tim Sekolah berdiskusi selama 2 jam tentang permasalahan pengajaran bahasa dan

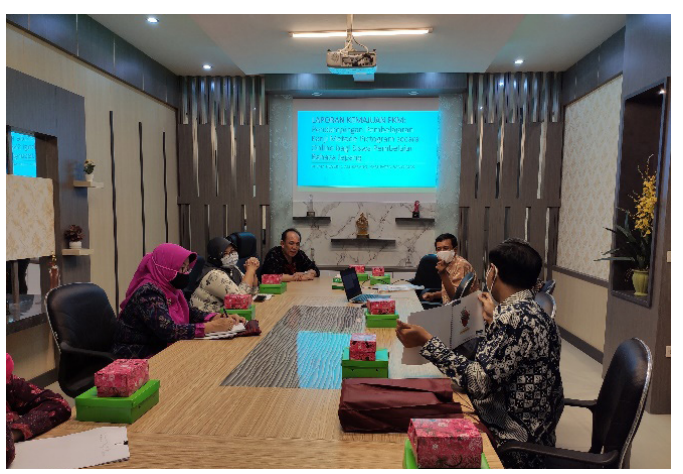

Gambar 2. Pemaparan Program PkM membicarakan peluang kerja sama terkait dengan pengajaran, penelitian, dan pengabdian masyarakat pada masa mendatang. Pihak sekolah melalui Kepala Sekolah sangat antusias dan terbuka bagi peluang-peluang kerja 
sama tersebut. Tim PkM juga mendapat banyak masukan tentang materi dan teknis pelaksanaan webinar yang akan dilaksanakan. Dalam kesempatan tersebut Tim PkM juga secara resmi menyerahkan 50 paket modul pembelajaran kanji yang akan dipakai oleh siswa dalam webinar dan bantuan buku-buku serta media pembelajaran bahasa Jepang. Setelah diskusi, acara dilanjutkan dengan peninjauan ruang kelas, perpustakaan, dan laboratorium bahasa dan komputer yang akan digunakan untuk memfasilitasi siswa yang kesulitan akses internet saat acara webinar nanti dilaksanakan.

\section{Tes Penjajagan Awal}

Pelaksanaan tes penjajagan awal ditujukan untuk mengetahui kemampuan siswa dalam penguasaan materi kanji JLPT N5. Materi tes diambilkan dari soal-soal ujian Kanji yang sudah keluar dalam beberapa tes JLPT sebelumnya. Bentuk soal, jumlah soal dan lama waktu ujian juga disesuaikan dengan ujian JLPT sebenarnya. Soal tes penjajagan awal berupa pilihan ganda dengan jumlah 25 buah dan dikerjakan dalam waktu maksimal 25 menit secara online menggunakan media Google Form. Tes awal ini dilaksanakan pada Senin, 13 September 2020 dengan dikoordinasi oleh guru pengampu bahasa Jepang. Dari 40 siswa yang mengikuti tes penjajagan awal ini, diperoleh nilai rerata 61 dari skala 100.

\section{Webinar}

Webinar dilaksanakan pada Jumat, 18 September 2020 pukul 10.00-16.00. Dengan memakai aplikasi Google Meet, 40 siswa SMAN 1 Ajibarang berpartisipasi dalam acara ini. Materi yang disampaikan meliputi peluang dan prospek belajar bahasa Jepang, JLPT dan arti pentingnya bagi pembelajar bahasa Jepang, arti penting pembelajaran huruf Kanji, pembelajaran Kanji metode pictogram, dan ditutup dengan diskusi serta tanya-jawab oleh Tim PkM dan guru pengampu bahasa Jepang.

Dalam sesi pertama, Bapak Eman Suherman selaku narasumber materi peluang dan prospek belajar bahasa Jepang, menjelaskan perkembangan pembelajaran bahasa Jepang di Indonesia dewasa ini yang memperlihatkan adanya animo dan minat yang besar masyarakat terhadap bahasa Jepang. Banyak masyarakat belajar bahasa Jepang di berbagai institusi pendidikan, baik secara formal maupun nonformal. Program Studi Bahasa dan Sastra Jepang banyak dibuka di berbagai perguruan tinggi di Indonesia,

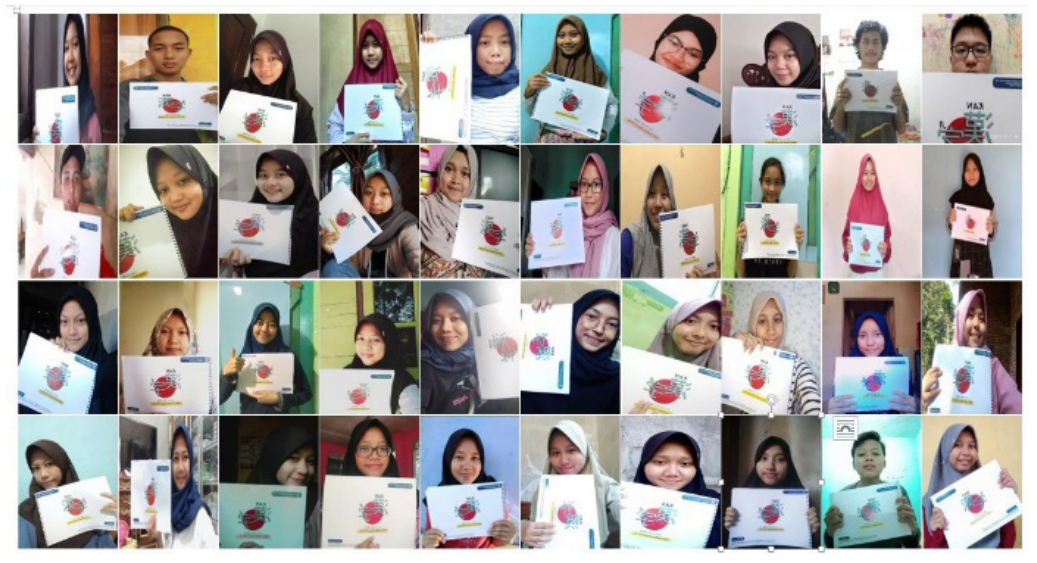

Gambar 3. Peserta webinar 
baik negeri maupun swasta. Banyak juga SMA/SMK yang menawarkan bahasa Jepang sebagai mata pelajaran bahasa asing di sekolah. Dalam pendidikan nonformal, kursus bahasa Jepang juga banyak ditemukan di berbagai kota besar. Terlebih lagi kursus bahasa Jepang yang terintegrasi dengan program magang bekerja di Jepang.

Narasumber juga memaparkan berbagai macam peluang dan prospek belajar bahasa Jepang seperti bisa bekerja di perusahaan Jepang, baik di dalam negeri maupun di luar negeri (Jepang), menjadi penerjemah bahasa baik freelance maupun di perusahaan. Selain itu, pembelajar bahasa Jepang juga bisa meraih peluang bekerja di sektor pariwisata seperti menjadi pemandu wisata, atau bekerja di hotel dan agen travel atau biro perjalanan wisata. Beberapa peluang juga bisa diraih di pemerintahan, seperti menjadi guru/dosen bahasa Jepang, bekerja di departemen luar negeri seperti menjadi diplomat, dan lain-lain.

Sesi kedua adalah pemaparan tentang arti penting mengikuti ujian JLPT bagi pembelajar bahasa Jepang dengan narasumber Bapak Najih Imtihani. Dalam kesempatan ini dijelaskan bahwa JLPT adalah ujian kemampuan bahasa Jepang bertaraf internasional yang diselenggarakan di 52 negara di dunia, mulai dari Australia, Indonesia, Amerika, Mesir, Brazil, dan lain-lain. Mengingat sertifikat ujian JLPT diakui di dunia internasional untuk keperluan pendidikan maupun pekerjaan/karier, penting bagi pembelajar bahasa Jepang untuk mempunyai sertifikat ini sebagai bukti kompetensi bahasa Jepang yang dimilikinya. Sertifikat JLPT berlaku seumur hidup dan bisa digunakan untuk melamar pekerjaan atau mendaftar kuliah di perguruan tinggi Jepang. Materi yang diujikan dalam ujian JLPT meliputi huruf (Kanji) dan kosakata, tata bahasa dan wacana, serta pendengaran (listening).

Sesi ketiga membahas huruf Kanji dan arti pentingnya dalam pembelajaran bahasa Jepang. Bapak Stedi Wardoyo selaku narasumber menjelaskan bahwa salah satu keunikan bahasa Jepang adalah menggunakan tulisan multihuruf ( fukusuu moji), yaitu Kanji, Kana (Hiragana dan Katakana), dan Romaji (huruf alphabet Romawi), serta angka Arab. Pada awalnya, bahasa Jepang belum mengenal huruf sampai mereka berinteraksi dengan Tiongkok dan mendapatkan bahwa pemerintah Tiongkok (dinasti Han) sudah menggunakan huruf dalam sistem administrasi mereka. Oleh karena itu, Jepang mengadopsi huruf Mandarin tersebut ke dalam bahasa Jepang. Huruf hasil adopsi tersebut dinamakan Kanji. Huruf Kanji merupakan huruf yang berbasis pada gambar dan mempunyai dua cara baca, yaitu cara baca Jepang (kunyomi) dan cara baca Mandarin (Onyomi). Karena merupakan gambar atau lambang dari suatu benda, sifat, atau kegiatan, jumlah huruf kanji sangat banyak. Akan tetapi, Kanji yang sering dipakai dalam kehidupan sehari-hari berjumlah 2.136 huruf dan dikenal sebagai Jouyou Kanji (Kanji sehari-hari).

Sesi keempat adalah acara inti webinar, yaitu pengenalan pembelajaran Kanji metode pictogram. Narasumber sesi ini adalah Bapak Widyantoro selaku guru Bahasa Jepang SMAN 1 Ajibarang dengan didampingi oleh dosen penutur asli bahasa Jepang di Program Studi Sastra Jepang UGM, bapak Matsushima Yukio. Dalam webinar ini diperkenalkan cara mudah untuk memahami dan menghafalkan Kanji dengan merujuk ke proses penyusunan Kanji atau melalui analogi asal usul Kanji. Pertama-tama diperkenalkan Kanji sederhana seperti angka, orang, dan alam seperti matahari, bulan, pohon, sawah, gunung, sungai, dan lain-lain. Selanjutnya diperkenalkan Kanji yang lebih rumit, yang merupakan kombinasi dari beberapa Kanji, seperti Yasumu/休む yang 


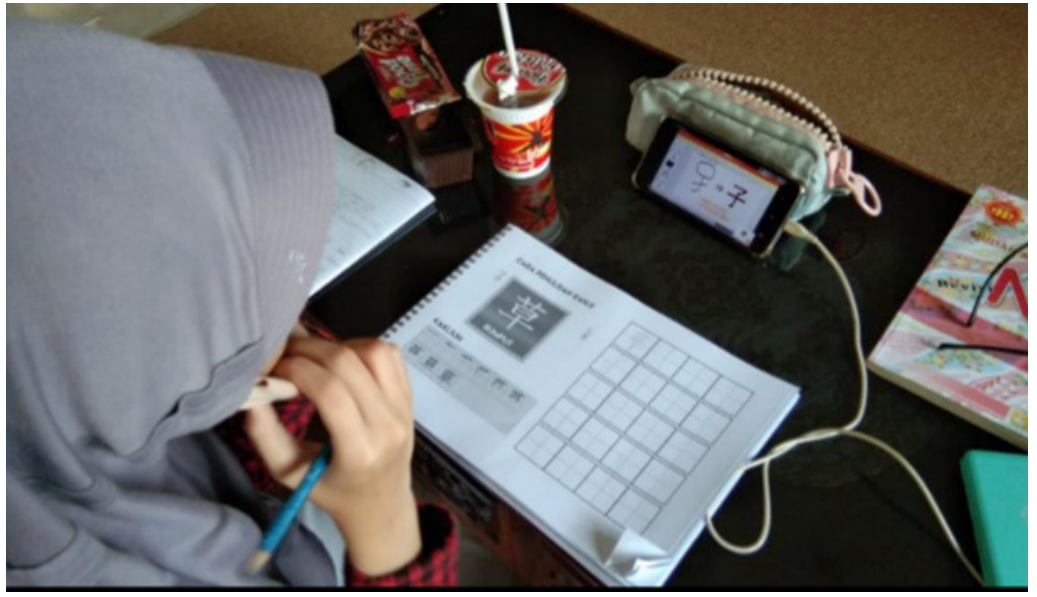

Gambar 4. Salah satu peserta sedang mengikuti pembelajaran secara online

merupakan kombinasi Kanji 'orang' (人) dan 'pohon' (木) yang bisa diartikan 'orang sedang beristirahat di pinggir pohon'. Dalam kesempatan tersebut juga ditayangkan video animasi pictogram Kanji yang sudah dibuat oleh tim PkM.

\section{Tes evaluasi akhir}

Tes evaluasi akhir dilaksanakan pada Senin, 21 September 2020. Tes akhir dilaksanakan untuk mengetahui apakah ada perubahan atau peningkatan hasil pembelajaran setelah siswa menjalani pembelajaran Kanji metode piktokgram. Dengan memakai aplikasi Google Meet, siswa mengerjakan tes akhir secara online dari rumah masing-masing. Bentuk soal, jumlah soal, dan lama waktu ujian juga sama dengan tes penjajagan awal, tetapi isi soal berbeda dengan soal tes awal meskipun keduanya diambilkan dari tes kanji JLPT sebelumnya. Tes akhir juga diikuti oleh 40 siswa yang dikoordinasi oleh guru pengampu bahasa Jepang dengan hasil nilai rerata 79 poin dari nilai total 100. Dari 40 siswa tersebut, 6 orang berhasil memperoleh nilai penuh 100 poin.

\section{Refleksi Capaian Program}

Berdasarkan hasil tes awal dan tes akhir siswa, bisa dilihat adanya manfaat program PkM ini dalam peningkatan nilai atau prestasi siswa. Jika dibandingkan dari hasil tes awal dan tes akhir, kita bisa melihat adanya peningkatan yang besar. Hasil rerata tes awal adalah 61, sedangkan rerata tes akhir adalah 79. Terlihat adanya fluktuasi nilai antara nilai ujian awal dan akhir, tetapi secara keseluruhan terlihat adanya peningkatan nilai rata-rata sebesar 18 poin. Meskipun perlu penelitian lebih lanjut untuk mengetahui faktor-faktor penyebab terjadinya fluktuasi nilai tersebut, dengan melihat peningkatan rerata nilai hingga 18 poin memperlihatkan adanya manfaat dan efek positif penggunaan metode pictogram dalam pembelajaran Kanji. Hal ini berkorelasi dengan kesan pesan peserta webinar yang sebagian besar menyatakan metode pictogram cukup membantu mereka dalam memahami dan mengingat Kanji.

Materi Kanji dalam ujian JLPT merupakan sebagian dari keseluruhan materi ujian yang meliputi kemampuan menyimak, tata bahasa, dan perbendaharaan kata, serta membaca. Untuk itu, pada masa mendatang dapat dikembangkan juga program 
Pengabdian kepada Masyarakat dalam upaya meningkatkan penguasaan materi ujian lainnya sehingga terbuka kemungkinan keberlanjutan program ini. Namun, berdasarkan masukan dan saran dari pihak sekolah, apabila pandemi Covid-19 telah berhasil diatasi dan situasi memungkinkan, program $\mathrm{PkM}$ diharapkan dapat diselenggarakan dalam bentuk kegiatan secara interaktif dan melibatkan siswa secara langsung seperti pelatihanpelatihan ataupun pengenalan budaya Jepang sehingga siswa lebih termotivasi dan memperoleh tambahan wawasan dalam mempelajari bahasa dan budaya Jepang.

\section{Penutup}

Setelah melalui berbagai tahapan, akhirnya Pengabdian kepada Masyarakat bertema "Pendampingan Pembelajaran Kanji Metode Pictogram kepada Siswa SMAN 1 Ajibarang, Kabupaten Banyumas" telah berhasil diselesaikan dengan baik dan lancar. Beberapa hasil atau keluaran program PkM ini, seperti buku latihan kanji JLPT N5 dan video pembelajaran Kanji metode pictogram dapat langsung dipakai dan dimanfaatkan oleh guru, siswa, maupun masyarakat umum dalam proses pembelajaran huruf Kanji. Sebagai tindak lanjut kegiatan $\mathrm{PkM}$ ini dan dalam upaya menyebarluaskan metode pictogram dalam pembelajaran Kanji, output PkM berupa video pembelajaran maupun buku latihan akan diunggah melalui kanal YouTube ataupun Kanal Pengetahuan Fakultas Ilmu Budaya UGM.

\section{Daftar Pustaka}

Chieko, K. dkk. (2002). Kihon Kanji 500 - Basic Kanji Book Vol. 1. Tokyo: Bonjinsha. Fusako, B., Watanabe Y., dan Kuramochi K. (2008). Sutoorii de oboeru Kanji 300 (Belajar 300 Kanji dari Asal-usulnya). Tokyo: Kuroshio Publishers.

Harian Kompas, 12 Maret 2020.

Hariri, T. dan Stedi W. (2017). Kanji Dasar. Buku Materi Ajar BJLT Bappenas, Pusat Bahasa FIB UGM.

Koichi, N. (2005). Reibun de Manabu Kanji to Kotoba (Belajar Kanji dan Kosakata melalui Contoh Kalimat). Tokyo: 3A Corporation.

Koichi, N. dan Kono T. (2005). Kanji in Context, Workbook Vol. 1. Tokyo: The Japan Times, Ltd.

Toyoko, T. (1990). Kanji no Michi - A Road to Kanji. Tokyo: Bonjinsha.

Yumiko, K. dkk. (2007). Kamji Master Vol. 1: 100 Kanji in 10 Days, The Easy Way. Tokyo: Senmon Kyouiku Shuppan.

\section{Sumber Internet}

http://kakijun.com/

https://www.chuden.co.jp/kids/denkipaper/2013/692/issue02.html

https://jepang.org/daftarkanji/

https://www.sukasuki.org/2020/01/

https://www.uni-passau.de/fileadmin/dokumente/hsg/nippon/Skripte/kanjibookjlptn5. $\mathrm{pdf}$ 